石油技術協会誌 第 77 巻 第 4 号 （平成 24 年 7 月） $241 \sim 249$ 頁 Journal of the Japanese Association for Petroleum Technology

Vol. 77, No. 4 (July, 2012) pp. 241 249

\begin{tabular}{l}
\hline 講 演 \\
Lecture \\
\hline
\end{tabular}

微化石研究の現状と石油地質学への応用

一古海洋環境変化とは何か一*

\author{
佐 藤 時 幸**
}

(Received July 31, 2012 ; accepted August 27, 2012)

\title{
Current Status on micropaleontology and its application to petroleum Geology
}

Tokiyuki Sato

\begin{abstract}
Micropaleontology has been used for both the determination of geological age and correlation to the Neogene-Quaternary formations in the oil fields in Japan. However, as it is against the rule of International stratigraphic guide to correlate to standard formations based on micropaleontology, it sometimes causes confusion of the stratigraphy of the oil fields.

Micropaleontology is a useful tool for not only the correlation to the geological age but also the paleoenvironment analysis. The ecology of calcareous nannoplankton is also applicable to reconstruct the stability of the surface ocean condition related to nutrient supply during the Miocene to Pleistocene. I describe in detail the characteristics of the microfossils both for the determination of geological age and for paleoenvironmental analysis, and introduce the utility of micropaleontology for petroleum exploration in this papaer.
\end{abstract}

Keywords: microfossil, stratigraphy, International stratigraphic guide, paleoenvironment, stability of the ocean, Neogene, Quaternary, oil fields

\section{1. はじめに}

微化石は少量の岩石試料に多数の個体を含むだけでな く, その種構成や群集組成が層準によってさまざまに変化 する特徴をもつ。このようなことから, 日本の石油鉱業 では地層対比の手段として 1930 年代にすでに底生有孔虫 化石の研究が開始されていた（大炊御門，1939など）。そ の後, Matsunaga（1963）の底生有孔虫化石層序や Shinbo and Maiya（1971）の浮遊性有孔虫化石層序の研究成果な どが次々に発表され, 石油鉱業では地下地質を把握する上 で微化石調査はなくてはならないものとなった。しかし， その有用性が逆効果となり, その後の我が国の石油鉱業に おける微化石層序の活用法は, 「微化石層序に基づいて地 層名を決定する」という本来の層位学の定義とかけ離れた 手法が一般化し（池辺ら, 1978 など), 油田地域の「地質 層序」は大きな混乱を招いてきた。すなわち, このような 層位学の誤つた使用法は, 石油探査で最も重要な地下構造 図に異なった定義で決定された地層名が混在するという大

* 平成 24 年 6 月 5 日, 平成 24 年度石油技術協会春季特別講演会にて講演 This special lecture was delivered at the 2012 JAPT annual meeting held in Akita, Japan, on June 5, 2012.

***秋田大学大学院工学資源学研究科 Faculty of Engineering and Resource Science, Akita University
きな問題を抱えることとなつた。

一方, 古生物研究に基づく古環境の復元では, 貝化石な ぞの大型化石や底生有孔虫などの底生生物化石を中心に発 達したが, 日本海側地域には地質年代決定に重要な種が産 しなかったことから，極めて不自然なまとめ方がされてき た。例えば “大桑・万願寺動物群” は, 「鮮新世を特徴づ ける寒冷海の貝類化石群集」として Otuka（1939）によつ て命名されたが, その後, 小笠原（1996）は「主として温 帯的な海洋気候下で繁栄したもので, 地域的・空間的に温 暖や泠温種が混在する」と総括した。これは “大桑・万願 寺動物群” が層位学的にも古環境学的にも大きな混乱があ ることを単に提示したにすぎなかつた。このような多くの 問題を整理したのが 1980 年代に飛躍的に進展した石灰質 ナンノ化石層序の研究成果であり, “大桑・万願寺動物群” がさまざまな地質年代にまたがるだけでなく, 古環境学的 にみても全く異なつた背景をもつ化石群を無理に一括して いたことを明らかにした（佐藤ら，1987, 1988a, b, 2012b； 高山ら，1988）。すなわち，それまでの古生物に基づく地 質年代決定の不精確さと, 古海洋環境変動の本質的な部分 が検討されないままの古環境解釈が, 多くの混乱を招き続 けていたことを示している。

一方, 近年の古海洋環境の復元では, 単に地質時代にお 
ける海洋環境の水温変化に注目するのではなく, その原因 を特定し, 水温のみならず海洋の水塊構造の変遷や水質の 変遷を含めた古環境復元が行われるようになっている。こ のような解析は, シークエンス層序学で重要なユース夕 シ一変動と密接に関連するばかりでなく, 石油根源岩分布 とも関連する海洋表層の栄養塩状態の恋遷を極めて具体的 に復元することができる。

本論では最初に油田地域における「層位学」の問題点を 述べ，近年明らかにされている高精度微化石年代層序学の 現状とその重要性を紹介する。引き続き，単に水温変動に 特化した古環境解析手法ではなく, 古海洋環境変化の持つ 本質的な意味を紹介し，微化石群集変化が示す古海洋環境 変動指標としての重要性と石油地質学におけるこれからの 役割について述べる。

\section{2. 微化石からの油田構造発達史復元}

\section{1 日本海側油田地域における層位学の基本的問題}

ISSC (International Subcommission on Stratigraphic Classification）は, 1994 年, アメリカ地質学会 (GSA) より「国 際層序ガイド」を発表した (Salvador, 1994)。これはそれ に約 20 年先立つ 1976 年に出版された「国際層序ガイド」 (Hedberg, 1976) にシークエンス層序学と関連する不整合 境界単元や磁気層序単元などを新しい章立てで書き加え たものである。このガイドは, 規約ではないものの IUGS (International Union of Geological Sciences) の小委員会で ある ICS (International Commission on Stratigraphy) が中 心となって「層序用語と層序学的手順の規則を発展させる こと（国際層序ガイド，日本地質学会訳，2001）」を目的 にまとめたもので，「訓告」として提供された。1976 年版 と 1994 年版では上述のような違いはあるものの, 層序区 分のカテゴリーに関しては基本的には変わりはない。これ は 1983 年にアメリカ石油地質家協会 (AAPG) に発表さ れた NACSN (North American Commission on Stratigraphic Nomenclature）の層序区分カテゴリーでもほぼ同様であ り，これが世界共通のものとして認識されている。すなわ ち, 石油地質学などでも特に重要で共通する基本的な層序 単元として

（1）岩相層序単元 (Lithostratigraphy)

(2) 生層序単元 (Biostratigraphy)

（3）年代層序単元 (Chronostratigraphy)

があり，それぞれが独立して定義されている。このうち， 岩相層序は岩体の岩相特性に基づき「層」や「部層」など の層序単元が，生層序は含有する化石に基づき「バイオゾ ーン (帯)」などの生層序単元が, 年代層序は岩体の地質 年代に基づき「統」や「階」などの層序単元が定義された。 したがって,「層」や「部層」などの単元は岩体の岩相特 性に基づいて区分されるカテゴリーであり，生層序とは明 確に区別される全く別のカテゴリーである。

このような国際的な層序カテゴリーに対し，我が国の石 油鉱業で用いられてきている地下油田層序の多くは,「下 部天徳寺層:No. 2 Grt. inflata bed の基底に設定する（佐賀,
1992)」や「C 層： $\mathrm{D}$ 層（西山層）との境界は, 浮遊性有 孔虫マーカーNo. 3 Globorotalia inflata Bed の下限に設定 した（石油公団，2000）などのように，地下地質層序の 地層区分, すなわち岩相層序単元が浮遊性有孔虫化石など の生層序単元で決定されている。このようなことから, 地 質調査所発行の秋田図副などの地下断面図では, 本来の岩 相層序単元に基づいた地表地質層序区分と，有孔虫化石な ぞの生層序単元に基づいた地下地質層序とが対比されるこ ととなり, 用語の使い方はもちろんのこと,「対比」その ものに大きな矛盾を含むこととなつた。日本海側油田地域 ではこのような混乱した層位学のため, 石油生成過程の解 析と密接に関係する古環境解析や構造発達史復元には大き な問題が含まれたままとなった。なお, 蛇足ではあるが,「上 部新生代」や「更新世下限」,「新第三系後期」のような誤つ た用語の使い方も，個々の用語が持つ意味の不理解が原因 である。

\section{2 油田形成史復元のために}

古環境の復元には, 精確な時間面と岩相変化, 底生生物 化石の群集解析などの研究が必要である。したがって, 坑 井間, および地表地質との対比では, 精確な時間面, 岩相 の三次元的変化, および底生生物化石相の変化などを個及 に独立させて解析した後, それらを相互に比較することで 詳細な復元が可能となる。そのためには, 精確な地質年代 の決定と対比が欠かせない。

\section{1）微化石による地質年代決定精度}

一般に, 浮遊性微化石の指標種は汎世界的に分布し，そ れによって汎世界的な生層序対比が容易に可能であると考 えられがちである。しかし, 多くの微化石は指標種の分布 域が限定されるため, 汎世界的な対比が直接に行えるわけ ではない。例えば珪藻化石や渦鞭毛藻化石などは, 大西洋 と太平洋間で指標種や化石帯が異なるだけでなく, 同じ大 洋でも海域によって指標種が違う。浮遊性有孔虫化石の場 合もBlow（1969）の化石帯が低緯度太平洋, 大西洋で追 跡できるものの, 中-高緯度では指標種が産出せず, 別に 独自の化石帯が設定されている。

これとは対照的に, 石灰質ナンノ化石は太平洋 - 大西 洋ーインド洋など各大洋の低緯度から高緯度まで共通の指 標種が分布することから, 汎世界的な地質年代の決定と対 比で最も有用な化石として注目されてきている。例えば,

Takayama and Sato（1987）によって設定された最上部新 生界の石灰質ナンノ化石対比基準面は, 大西洋からインド 洋，太平洋までの中高緯度海域のみならず，アリューシャ ン海域（Sato et al., 2002）や北極海域（Sato and Kameo, 1996）まで追跡できることが明らかにされている。すなわ ち, 石灰質ナンノ化石は, 地質年代層序のヨーロッパ標準 時階を同じ指標種で汎世界的に直接追跡可能であることを 示唆している。

図 1 は, Sato et al.（2009）および佐藤ら（2012a）によっ てまとめられた最上部新生界の石灰質ナンノ化石対比基準 面と古地磁気層序および酸素同位体層序 (LR04; Lisiecki and Raymo, 2005）との関係を示している。一般には，こ 


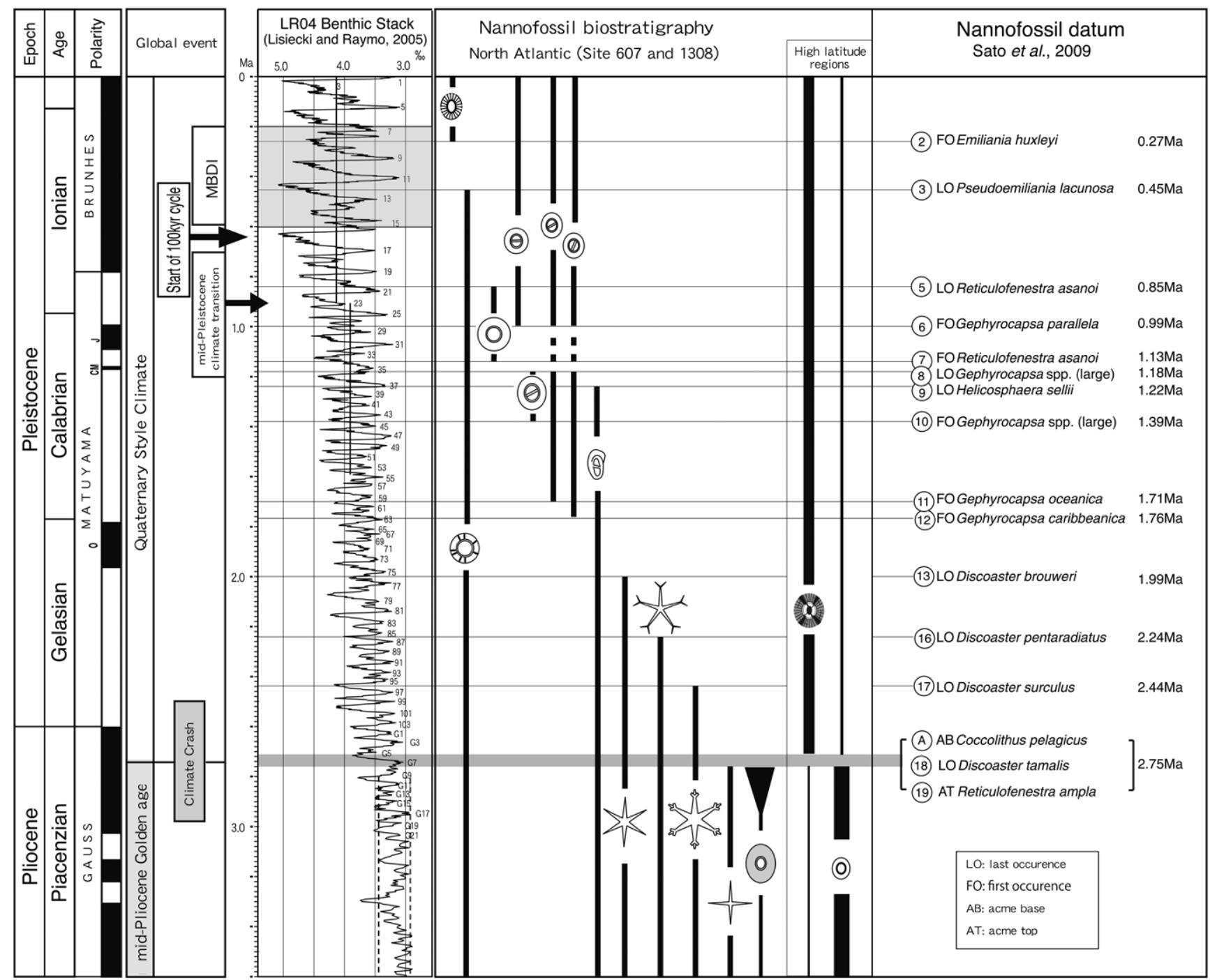

図 1 最上部新生界の石灰質ナンノ化石対比基準面と地磁気層序, 酸素同位体層序, 標準時階との対比, および汎世界 的な地質イベントとの対応。LR04の図にある番号は MIS を示す（MIS：Marine Isotope Stage）

のような相互関係が汎世界的な規模で追跡できるかどうか が問われる。このことと関連して，佐藤ら（2012a）は， 石灰質ナンノ化石対比基準面 2 (Emiliania huxleyi の産出 下限), 基準面 3 (Pseudoemiliania lacunosa の産出上限) と酸素同位体ステージとの関係について北大西洋と西太平 洋のコアを用いて比較し，ともに MIS 8 と 12 に位置する だけではなく, 基準面 2 と 3 はいずれの海域においても各 ステージの最大ピークを示す層準のわずかに下位に位置す ることを示した。すなわち、北大西洋と西太平洋という遠 く離れた地域間においても，石灰質ナンノ化石対比基準面 が極めて高い同時間性を持っていることを明らかにした。

このような高い地質年代の決定精度は, 後述する地質構造 発達史の復元や古環境解析において極めて重要な役割を 担う。

\section{2）石灰質ナンノ化石年代からの油田構造解析}

本来, 古環境解析では岩相の三次元的分布様式に時間面 を加えることによって, 四次元での油田構造形成史が復元 される。しかし, 前述のように日本海側油田地域の層序は, 岩相層序，年代層序，化石層序の定義が理解されないまま
まとめられてきたため, 岩相の時空分布変化を精確に捉え ることができない。

近年, 佐藤ら（2012b） は秋田県由利本荘市から沖合 に東西に並ぶ坑井に石灰質ナンノ化石対比基準面を追跡 し、秋田平野の海岸線に沿って延びる北由利衝上断層群が $\mathrm{NKH}-1$ 号井と 3 号井の間に位置し, その活動 (インバージョ ンテクトニクス）が $3.85 \mathrm{Ma}$ 付近で始まり $1.71 \mathrm{Ma}$ に終了 したこと, 同時にこの活動が “桂根相” と呼ばれるタービ ダイト砂岩の分布を規制したことなどを明らかにした（図 2)。さらに彼らは北由利衝上断層群の活動終了とともに新 たな逆断層の活動が本荘の沖合で発生し, $1.71 \mathrm{Ma}$ 以降現 在までに $1000 \mathrm{~m}$ 以上の落差をもたらしたことを示した (図 2)。すなわち, このような三次元の岩相分布様式に正確な 時間面の追跡を加えることによって, 詳細な構造発達史の 復元と岩相分布様式変化の原因が初めて明らかになること を示唆している。

このような地域的な構造運動とは別に, 汎世界的な地質 イベントを日本海側に分布する上部新生界に追跡したの が図 3 である。鮮新世以降, 地球環境変動のイベントはさ 


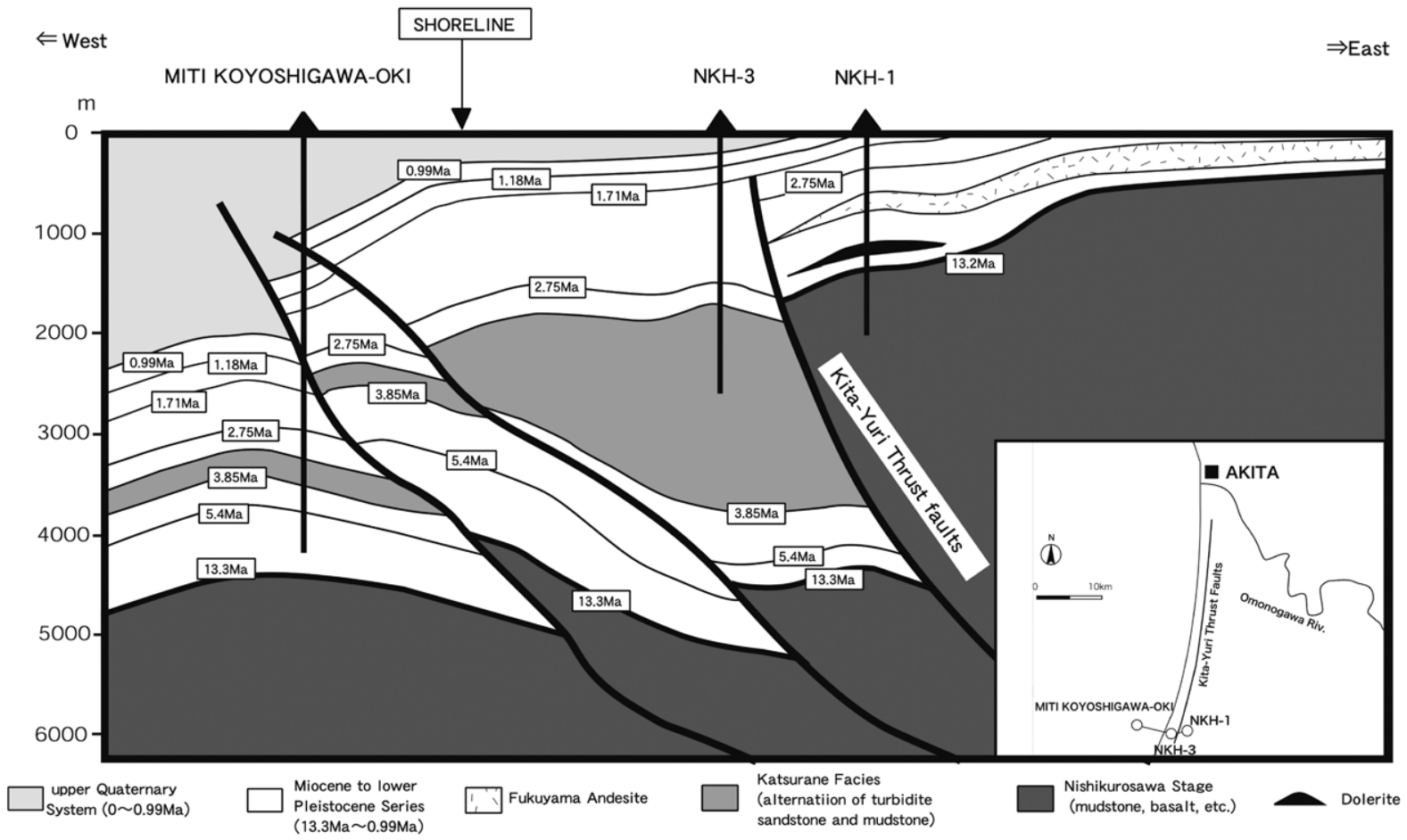

図 2 秋田県由利本荘市の海岸線に直交する東西地下断面図

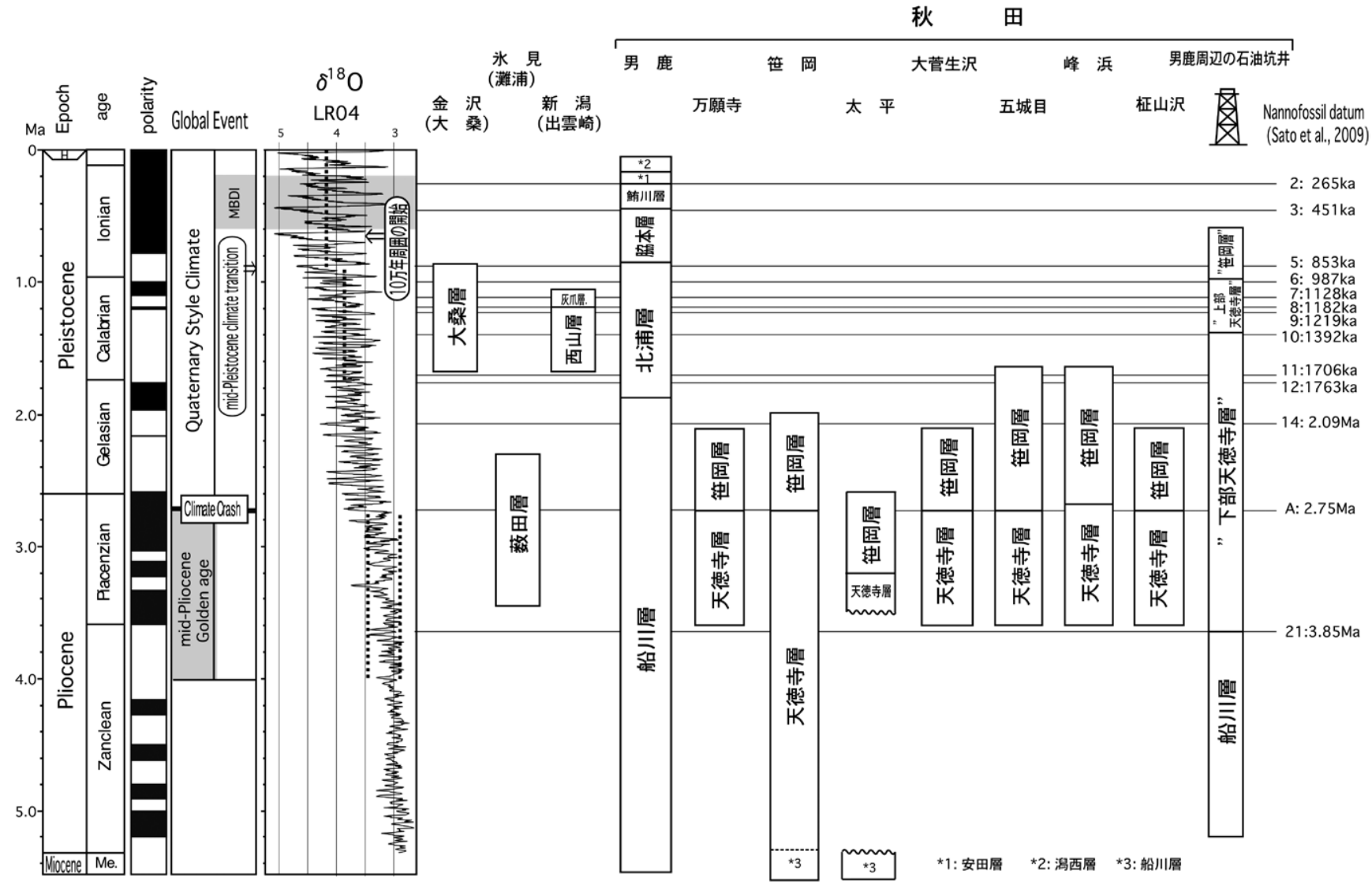

図 3 日本海側地域に分布する最上部新生界の対比と酸素同位体層序，地磁気層序，ヨーロッパ標準時階との対比，お よび汎世界的な地質イベントとの対応

まざまで, 中でも鮮新世中頃の mid-Pliocene Golden age と 呼ばれる温暖期, その終わりに発生したパナマ地峡の成 立（パナマ海域の陸化による太平洋 / 大西洋間の流通の遮
断）と関係する Climate Crash などは, 日本海側油田地域 に強い影響を及ぼした注目されるイベントである。すなわ ち, mid-Pliocene Golden age の汎世界的な温暖期はいわゆ 
る no. 3 Globorotalia inflata bed に対応し，日本海側一帯に 温暖な外洋水の影響をもたらした。しかし，その終わりに は，パナマ地峡の成立による強い寒冷化と海水準低下をも たらした Climate Crash が発生し，それによって秋田油田 地域一帯は半深海性シルト岩よりなる天徳寺層から浅海性 砂質岩よりなる笹岡層へ岩相変化した（図 3)。このよう な時間面と岩相の解析結果は，それぞれを別個に調査した 上で比較検討することにより初めて明らかになるものであ り, 層位学の基本が如何に重要であるかを示唆している。

\section{3. 古環境変動とは何か?}

\section{1 化石群集変化が意味するもの}

近年，小笠原（2011）は貝化石を中心に解析したグロー バルな古海洋事件が, 各大洋間の流通の変遷に大きく影 響されていたことを述べた。しかし，このような古海洋 環境の変遷とテクトニクスイベントとの関係は，すでに Zachos et al. (2001) など多くの論文によって, 地球のテ クトニックイベントと酸素同位体変動，それによって発生 した気候変動イベントなどに注目して詳細にまとめられて きている。そもそも，このような研究は 1970 年代より国 際深海掘削計画 DSDP-ODP を通じて微化石や同位体層序 などに注目して数多くの論文で述べられてきたことであ る。例えばオーストラリア / 南極大陸間の海域である夕ス マニア回路の成立に関しては DSDP Leg28の成果（Hayes and Frakes, 1975 など）を初めとして多くの成果が発表さ

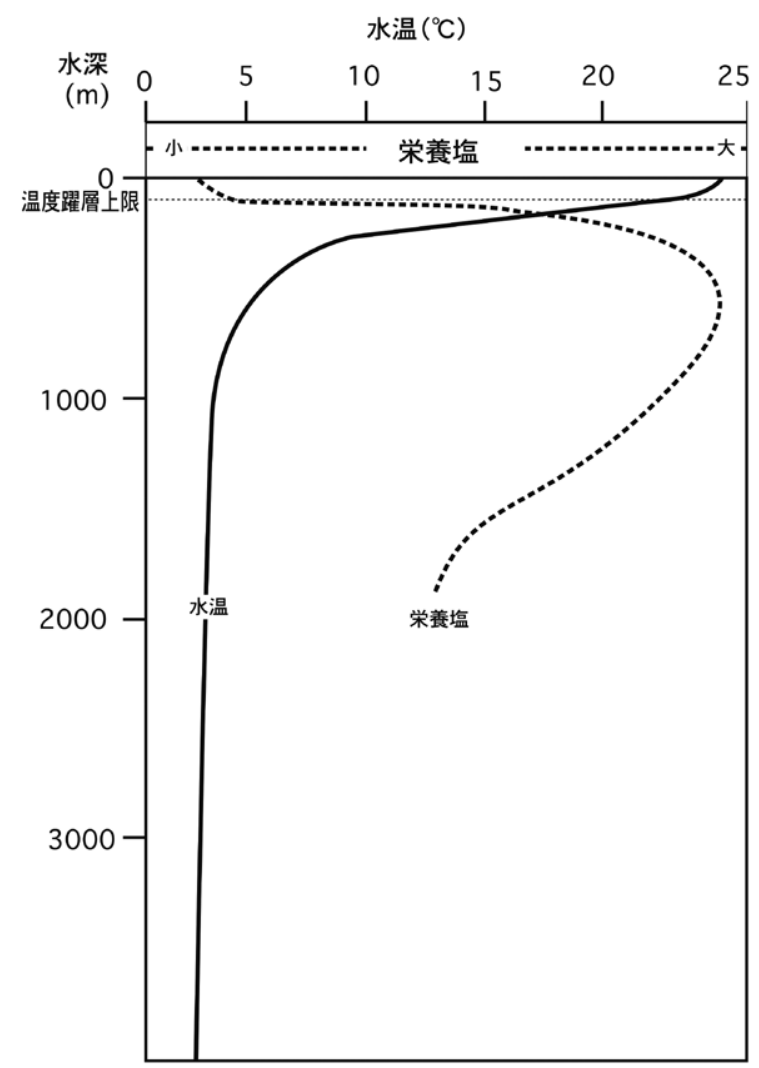

図 4 低一中緯度海域の標準的な垂直温度変化と栄養 塩量変化，および温度躍層上限の深度
れた。中でも Kennett（1977）は，始新世 / 漸新世境界で の南極大陸周回流の発達による南極大陸の温度隔離が，南 極大陸の水床形成に強く関与したことを指摘している。同 様に佐藤ら (2012a) によって概要が紹介されているパナ マ地峡の成立に関しては，1970 年代から 2010 年までの間 の多くの研究によって議論されてきた。すなわち，275 万 年前の大西洋 / 太平洋間の流通の遮断がなぜ北極の水床拡 大を招き，地球を寒冷化させたのかについて，単に暖流の 遮断だけではなく, 大西洋と太平洋間のステリックハイト （海面熱フラックスによる水位変動）と，それに伴うアル ベド（入射光に対する反射光の比）の変化などが原因であ り，それによって北極海域の氷床が急激に発達したことが 極めて具体的に明らかにされた（例えば Sato et al., 2004, Bartoli et al., 2005)。これらの成果は 2011 年に IUGSによっ て新第三系 / 第四系境界の定義をカラブリアン階基底から ジェラシアン階基底に変更するための最も重要なポイント になった（佐藤ら（2012a）を参照)。

そもそも，それまで第四系の基底がカラブリアン階基底 で誤って定義されていたのは，模式地において貝化石や貝 形虫化石などの寒冷種がカラブリアン期より出現すること にあった。しかし，佐藤ら（2012a）が指摘したごとく, このような貝化石や貝形虫化石などが示す寒冷化は, 汎世 界的な気候変動とは全く異なり, ごく地域的な変化でしか ない。そのことが新第三紀 / 第四紀境界の境界設定に大き な混乱を与えてきたことは逆の意味で注目すべきことであ ろう。すなわち, 新第三紀 / 第四紀の定義 1 つをとつも, これまでの古生物学的データの活用法は主にごくローカル な水温変動と古水深に注目した古環境解析に利用されてき た。しかし, 生物の生態は, 本来は水温や水深のみならず 塩分や栄養塩, 溶存酸素量など, さまざまな要因の影響を 受ける。すなわち, 古生物群集の変化は, 必ずしも水温や 水深の変化が作用した結果とは限らない。図 4 は熱帯およ び温帯の一般的な海水温の垂直変化であるが，通常，水深 $100 \mathrm{~m}$ 付近を境に海水温が低下し始め栄養塩量が増加す る（温度躍層と栄養塩躍層の上限）。すなわち, 熱帯から 温帯の海域の海洋表層は, 温暖で貧栄養の水塊で覆われて いるのが一般的である。このような海洋表層の栄養塩に注 目して, Falkowsky et al. (2004) は大陸の分裂や緯度間の 温度勾配拡大, それらに伴う海洋循環速度の増加による海 洋表層の擋汼が海洋表層を富栄養化させ, 海洋表層で生息 するプランクトンが $K$ 戦略者（世代交代の長期化（少産） とサイズの大型化）優勢から $r$ 戦略者（世代交代の短期化 （多産）とサイズの小型化）優勢へと変化することを示し た。さらに, 佐藤 ・千代延（2009） は, 海洋表層の安定時 と湧昇流などによる崩壊時における石灰質ナンノ化石群集 組成の違い（図 5）に注目し，始新世から鮮新世のコッコ リス（石灰質ナンノ化石）サイズ変化と上部透光帯種（主 に $0 \sim 100 \mathrm{~m}$ の水深に生息し，栄養塩より光（光合成）を 選択）および下部透光帯種（主に $100 ２ 00 \mathrm{~m}$ の水深に生 息し, 光（光合成）より栄養塩を選択）の生産量変化を調 査した。その結果, 始新世 / 漸新世境界を境とした南極大 


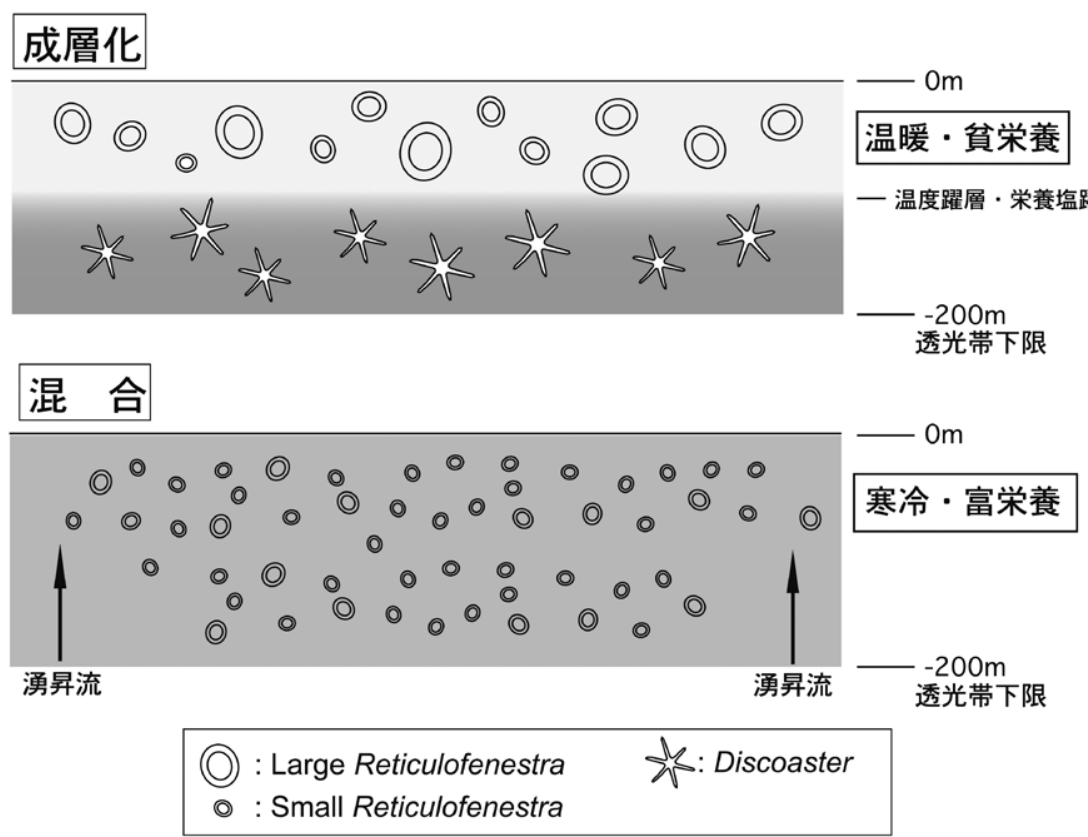

図 5 海洋表層の成層構造が発達する場合と混合（湧昇流などによる成層構造の崩壊）の際の石灰質ナンノ化石群集組 成の違い

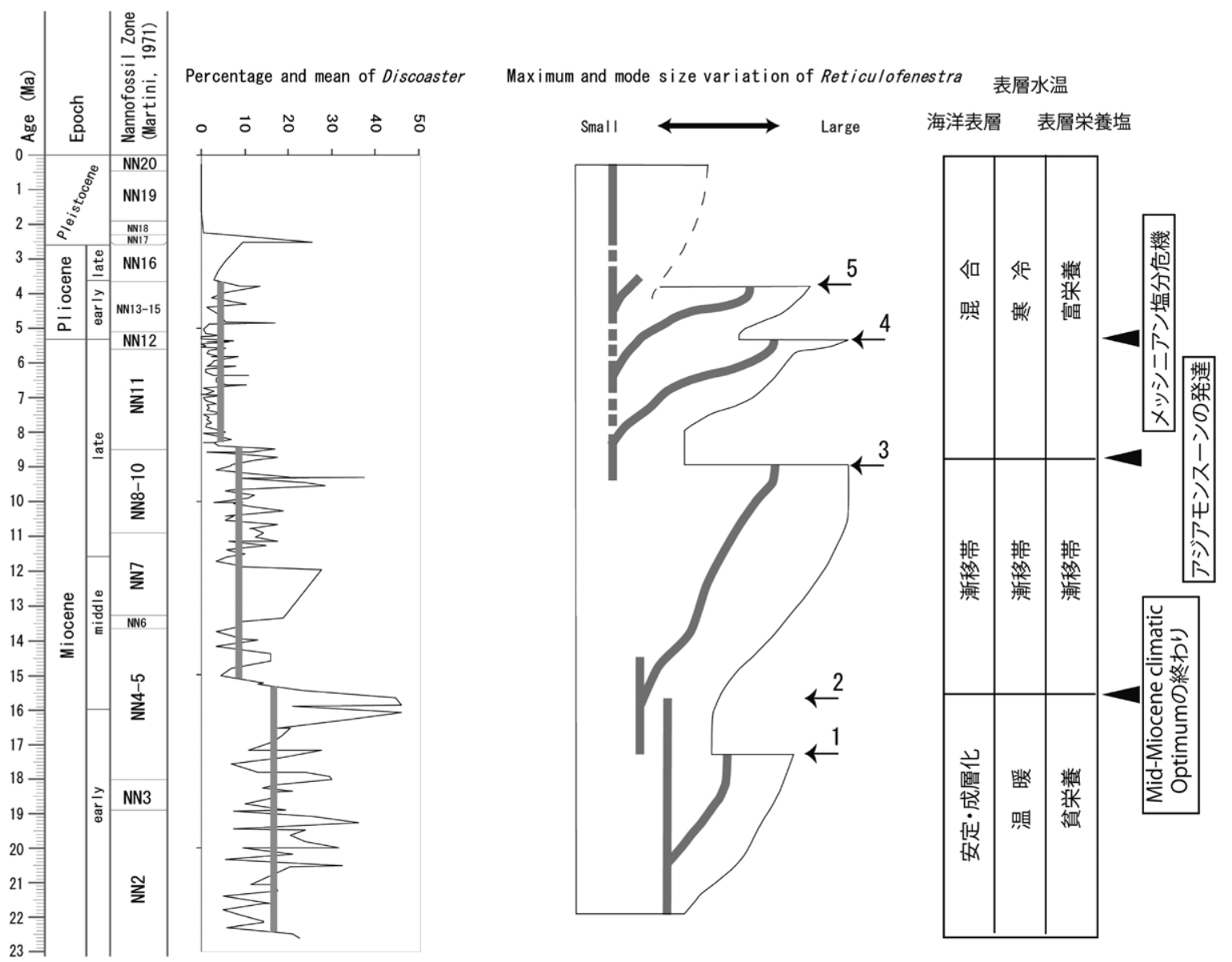

図 6 中新世から更新世における下部透光帯種 Discoaster の相対頻度変化とReticulofenestra 属の最大サイズ変化，およ び海洋表層の安定度，表層水温，表層の栄養塩，および地質イベントとの関係（Farida et al. (2012）を一部修正）

陸とオーストラリア大陸の分離による南極周回流の成立, 中新世末で地中海の干上がりを示唆するメッシニアン塩分 危機，およびカラブリアン期 / ピアセンジアン期境界で
のパナマ地峡の成立が，海洋表層構造の安定性を順次崩壞 させ, 海洋表層の寒冷化と富栄養化を促進させたことを示 した。さらに近年, Farida et al. (2012) は, 西赤道太平洋 
の Hole805B における石灰質ナンノ化石群集解析を行い, 中期中新世初めの NN4-NN5 と, 後期中新世中頃の NN10/ NN11 境界の 2 回に下部透光帯種Discoaster の相対頻度が 段階的に減少すること, およびそれと連動して Reticulofenestra 属の最大サイズが突然縮小することなどを指摘した (図 6)。彼女らが指摘したこれら群集変化のタイミングは, それぞれ（1）中期中新世初めの温暖化 mid-Miocene Climatic Optimum の終了時期（Flower and Kennett, 1995), および(2)アジアモンスーンの発達時期（Zhisheng et al., 2001;Zachos et al., 2001; Zheng et al., 2004）と一致する（図 6)。すなわち, Discoaster 属の相対頻度減少は海洋表層の 安定度が段階的に失われ表層の富栄養化が進行したことを 示唆し, その原因がインドネシア多島海の成立による南極 大陸の氷床拡大と寒冷化 (mid-Miocene Climatic Optimum の終了), およびヒマラヤ山脈の高度化によるアジアモン スーンの発達にあることを示している。これはいずれも緯 度間の温度較差の拡大, もしくはモンスーン気候の強化に よる大気循環の変化による海洋循環速度の増加が原因であ り, プランクトン群集の変化が海洋循環の変化による水塊 構造の変動に最も敏感であること, 水温変動はそのような 海洋表層構造の変化が原因であることを示している。すな わち, 微化石が示す群集変化は, 古水温変化を示すのでは なく, 古水温変化の原因そのものを示している。

3.2 微化石研究から石油地質へのアプローチ

\section{堆積速度変化}

一般に石油鉱業において, 微化石研究は坑井間の層序 対比と古環境解析に主眼をおいて実施されてきた。しか し, 近年の微化石研究の進展は, 地質年代決定精度の飛 躍的向上と, 古環境変動の根本的な意味の解明に大きな影 響を及ぼしている。すなわち, 地質年代決定精度の向上は 単に対比精度を向上させただけではない。この成果を端的 に示したのが佐藤ら（2008）の微化石調査結果である。彼 らはべトナム沖で掘削された坑井の地質年代を詳細に決 定し, $0.50 \mathrm{Ma}$ か $1.27 \mathrm{Ma}$ 間と2.54 Maから $4.18 \mathrm{Ma}$ 間 の 2 層準に不整合があることを指摘した。この不整合は $2.75 \mathrm{Ma}$ のパナマ地峡成立に伴う北極海域の水床拡大と, Mid-Pleistocene climate transition と呼ばれる $0.9 \mathrm{Ma}$ での平 均酸素同位体值の増加（図 1) に対応し, 彼らはそれに伴 う海水準の低下が不整合の原因であることを指摘した。さ らに重要なことは, $0.50 \mathrm{Ma} / 1.27 \mathrm{Ma}$ 間の不整合より上位 の堆積速度が, その下位の堆積速度, $60 \mathrm{~cm} / \mathrm{ky}$ から 6 倍 以上の $382 \mathrm{~cm} / \mathrm{ky}$ へ変化したことを指摘し, その堆積速 度の変化が MPR 以降に発達する強い振幅の 10 万年の水 期 / 間水期変動周期が原因であることを明確にした。

このように, 地質年代の決定精度は単に詳細な地質年代 の決定と詳細な坑井間対比を可能にするばかりでなく, そ の年代值と求められた堆積速度の変化は, 研究対象地域で 発生した環境変動の時期や, ユースタシー変動などのグ ローバル環境変動との関連性について重要な示唆を与え る。すなわち, 堆積速度変化は石油貯留岩分布や根源岩分 布予測に極めて重要な情報を提供することになる。
古環境変動：石油根源岩分布予測に向けて

初めに述べたように, 古生物群集の変化はともすれば単 に水温変化の影響を受けたと考えられがちであるが, 群集 変化は水温変化の原因とそれに伴う栄養塩量などの水質変 化を詳細に提示している。古第三紀から現在に向かっての 石灰質ナンノ化石の小型化は, Falkowsky et al. (2004) が 指摘のごとく, 大陸の配置変化に伴う海洋の富栄養化を示 しており, 同時に Farida et al. (2012) は西赤道太平洋で の Discoaster の段階的減少（図 6) が海洋表層構造の段階 的崩壊を示唆し，それが富栄養化を招いたことを示した。

初めに示したように, 寒冷化 / 温暖化を単純に地域的な 現象として判断するには大きな問題がある。すなわち, 環 境変動の発生については大なり小なり他地域との連動した 変化であるため, その原因を特定しない限り意味をなさな い。また, 温暖化, 寒冷化の変化は熱を供給する太陽の問 題もあるが, 多くは熱を受ける地球の熱の受け方が原因で あり，それによってさまざまな環境変動が発生する。その 際に重要なことは, 以下の点についてである。

1）陸の配置変化

2) 緯度間の水温較差

3）海洋表層構造の崩壊

そのうち, 陸の配置は海流の流路を変えるばかりでなく, 海洋表層構造の安定性を崩壊させ, 時には温度躍層以深の 冷たく栄養豊富な海水を表層に供給する（湧昇流）。この ことにより極域では氷床が拡大し, 緯度間の水温較差が拡 大するため, 海洋表層構造の安定性は崩壊することになる。 すなわち, 石油地質学の観点からすると, 海洋表層の安定 性崩壊とそれによる栄養塩の海洋表層への供給は, プラン クトンなどの生物生産量を増大させ, 結果として堆積物中 へ混入する有機物量を増大させる（図 5)。もちろん, 石 油根源岩の形成では, 有機物が堆積岩に保存されるまでの 過程 (分解) も問題となるものの, 表層の栄養塩量はプラ ンクトン類の生産に極めて大きな貢献をする。秋田地域の 中新統女川層やカリフォルニアのモンテレー層のような珪 藻化石の濃集・堆積は, mid-Miocene Climatic Optimum の 終了とともに太平洋の循環システムが大きく変化したため であり, 加えて $10 \mathrm{Ma}$ 前後のモンスーン気候の強化が太 平洋縁海での海洋表層の富栄養化を促進させたことによる。

\section{4. おわりに}

本稿では, 石油鉱業における微化石研究の役割と重要性 について紹介した。とくに, 石油鉱業における「岩相層序」, 「化石層序」,「時間層序」といつた層位学の混乱は, 石油 地質学のみならず地球科学の進展に大きな支障をきたすこ とになる。解析すべきは, 精度の高い地質年代の決定とそ れとは別に確立された岩相層位学との組み合わせであり, それによって初めて構造発達の詳細が見えてくる。同様に 古環境解析の面でも, 単に各地域の水温や水深変化の解析 に利用されてきた古生物学的データについて, 化石群集変 化そのものが持つ本質的な意味を理解することが大事で ある。

J. Japanese Assoc. Petrol. Technol. Vol. 77, No. 4 (2012) 
すなわち, 微化石研究が今後とも石油地質に寄与するに は, 層位学の本質に立ち返つたうえで, 精度の高い地質年 代決定と対比を行うことはもちろんのこと, 微化石群集変 化が単に古水温変化のような表面上の変動を示すのではな く, その古環境変化の原因となる本質を示していることに 注目しない限り進展はない。

\section{謝 辞}

本稿は, 平成 24 年度石油技術協会総会で講演した内容 を一部修正してまとめたものである。講演と本稿の発表の 機会をいただいた石油技術協会に御礼申し上げる。

\section{引用 文 献}

Bartoli, G., Sarnthein, M., Weinelt, M., Elrenkeuser, H., Garbe-Schonberg, D. , and Lea, D. W., 2005 : Final closure of Panama and onset of northern hemisphere glaciation. Earth Planet Science Letter, 237, 33-44.

Blow, W. H., 1969 : Late middle Eocene to recent planktonic foraminiferal biostratigraphy. Proc. $1^{\text {st }}$ Internat. Conf. Plank. Microfossils, Geneva 1967, 1, 199-421.

Falkowsky G. P., Schofield, O., Katz, M. E., Van de Schootbrugge, B., and Knoll, A. H., 2004 : Why is land green and the ocean red? In Thierstein, H. R. and Young, J. R., eds.: Coccolithophores from Molecular Processes to Global Impact, 429-453, Springer.

Farida, M., Imai, R., and Sato, T., 2012 : Miocene to Pliocene paleoceanography of the western equatorial Pacific Ocean based on calcareous nannofossils, ODP Hole 805B. Open Journal of Geology, 2, 72-79.

Flower, B. P. and Kennett, J. P., 1995 : Middle Miocene deepwater paleoceanography in the southwest Pacific: Relations with east Antarctic ice sheet development. Paleoceanography, 10, 1095-1112.

Hayes, D. E. and Frakes, L. A., 1975 : General synthesis, Deep Sea Drilling Project Leg 28. In Hayes, D. E., Frakes, L. A., et al., Initial Reports of the Deep Sea Drilling Project, 28. Washington (U.S. Government Printing Office), 919-942.

Hedberg, H. D. ed., 1976 : International Stratigraphic Guide. John Wiley and Sons.

池辺 穣・片平忠実・宮崎 浩, 1978 : 我が国におけるセ キ工地質学的諸問題. 日本の新生代地質, 池辺展生教授 記念論文集, 205-216.

Kennett, J. P., 1977 : Cenozoic evolution of Antarctic glaciation, the Circum-Antarctic Ocean, and their impact on global paleoceanography. Journal of Geophysical Research, 82, 3843-3860.

Lisiecki, L. E. and Raymo, M. E., 2005 : A Pliocene-Pleistocene stack of 57 globally distributed benthic $\delta^{18} \mathrm{O}$ records. Paleoceanography, 20, PA1003.

Matsunaga, T., 1963 : Benthic smaller foraminifera from the oil fields of northern Japan. Science Reports of the Tohoku
Univ. $2^{\text {nd }}$ series (Geol.), 35, 67-122.

日本地質学会訳編, 2001 : 国際層序ガイド. 共立出版(株).

North American Commission on Stratigrahic Nomenclature, 1983 : North American Stratigraphic Code. The American Association of Petroleum Geologists Bulletin, 67, 541-875.

小笠原憲四郎, 1996 : 大桑 - 万願寺動物群の古生物地理学 的意義. 北陸地質研究所報告, 5, 245-262.

小笠原憲四郎, 2011 : 本邦新生代の地質・古環境事件とそ の原因. 石技誌, 76(4)，284-291.

大炊御門經輝, 1939 : 新潟県小千谷町東方野辺川谷に発達 する第三系の有孔虫化石群に就いて. 日本古生物学会報 告, 46, 455-460.

Otuka, Y., 1939 : Tertiary crustal deformation in Japan (with short remarks on Tertiary paleogeography). Jubilee Publication in the Commemoration of Professor H. Yabe's Sixtieth Birthday, 481-519.

佐賀 肇, 1992 : 秋田山形地域, 天然赤又鉱業会・大陸棚 石油開発協会編：改訂版日本の石油・天然ガス資源, 57, 天然方鉱業会，大陸棚石油開発協会 .

Salvador, A. ed., 1994 : International Stratigraphic Guide $2^{\text {nd }}$ Edition. Geological Society of America.

佐藤時幸 -千代延俊, 2009 : 石灰質ナンノ化石サイズ変化 と Discoaster 生産量からみた新生代古海洋変動. 化石, 86, $12-19$.

佐藤時幸・千代延俊・ファリーダ メウティア, 2012a： グローバル気候変動と新第三紀の終わり/第四紀の始ま り一石灰質ナンノ化石層序から一. 地質学雑誌, 118 , $87-96$.

Sato, T., Chiyonobu, S., and Hodell, D. A., 2009 : Quaternary calcareous nannofossil datums and biochronology in the North Atlantic Ocean, IODP Site U1308. Proc. IODP, 303, $1-9$.

佐藤時幸・長谷川修太郎・山崎 誠 - 中川 洋, 2008：地 球環境変動からみたベトナム沖海域に発達する不整合. 平成 20 年度石油技術協会春季講演会要旨集, 35 .

Sato, T. and Kameo, K., 1996 : Pliocene to Quaternary calcareous nannofossil biostratigraphy of the Arctic Ocean, with reference to late Pliocene glaciation. In Thiede, J., Myhre, A.M., Firth, J.V. et al. eds : 1996. Proc. ODP, Sci. Results, 151 : College Station, TX (Ocean Drilling Program), $39-59$.

Sato, T., Saito, T., Yuguchi, S., Nakagawa, H., Kameo, K., and Takayama, T. , 2002 : Late Pliocene calcareous nannofossil paleobiogeography of the Pacific Ocean : Evidence for glaciation at 2.75Ma. Revista Mexicana de Ciencias Geologicas, $19,175-189$.

佐藤時幸 - 佐藤伸明 - 山崎 誠 - 小川由梨子 - 金子光好, 2012b：石灰質ナンノ化石からみた秋田地域の新第三紀 ～第四紀古環境変動. 地質学雑誌, 118, 62-73.

佐藤時幸・高山俊昭 - 加藤道雄 工藤哲朗, 1987 : 日本海 側に発達する最上部新生界の石灰質微化石層序, その 1 : 
新潟地域. 石技誌, 52(3), 231-242.

佐藤時幸 - 高山俊昭 - 加藤道雄 - 工藤哲朗, 1988a : 日本海 側に発達する最上部新生界の石灰質微化石層序，その 3 : 秋田地域および男鹿半島. 石技誌, 53(3), 199-212.

佐藤時幸 - 高山俊昭 - 加藤道雄 - 工藤哲朗 - 亀尾浩司, 1988b：日本海側に発達する最上部新生界の石灰質微化 石層序, その 4 : 総括一太平洋側および鮮新統 / 更新統 境界の模式地との対比. 石技誌 , 53(6), 475-491.

Sato, T., Yuguchi, S., Takayama, T., and Kameo, K., 2004 : Drastic change of the geographical distribution of the cold water nannofossil Coccolithus pelagicus (Wallich) Schiller during the late Pliocene -with special reference to increase of ice sheet in the Arctic Ocean-. Marine Micropaleontology, 52, 181-193.

石油公団, 2000 : 平成 11 年度基礎試錐「小国」地質検討 会資料.

Shinbo, K. and Maiya, S., 1971 : Neogene Tertiary planktonic foraminiferal zonation in the oil-producing provinces of Japan. In Stratigraphic correlation between sedimentary basins of the ECAFE region (second volume). United Na- tions, Mineral Resources Development series, 36, 135-142. 高山俊昭 - 加藤道雄 - 工藤哲朗 - 佐藤時幸 - 亀尾浩司, 1988 : 日本海側に発達する最上部新生界の石灰質微化石 層序, その 2 : 北陸堆積盆地. 石技誌, 53(1), 9-27.

Takayama, T. and Sato, T., 1987 : Coccolith biostratigraphy of the north Atlantic Ocean, Deep Sea Drilling Project Leg 94. In Ruddiman, W.F., Kidd, R.B., Thomas, E., et al., Init. Repts. DSDP, 94 (Pt. 2). Washington (U.S. Government Printing Office), 651-702.

Zachos, J., Pagani, M., Sloan, L., Thomas, E., and Billupt, K., 2001 : Trends, rhythms, and aberrations in global climate 65 Ma to Present. Science, 292, 686-693.

Zheng, H., Powell, C. M., Rea, D., Wang, J., and Wang, P., 2004 : Late Miocene and mid-Pliocene enhancement of the East Asian monsoon as viewed from the land and sea. Global and Planetary Change, 41, 147-155.

Zhisheng, A., Kutzbach, J. E., Prell, W. L., and Porter, S. C., 2001 : Evolution of Asian Monsoons and phased uplift of the Himalaya-Tibetan plateau since Late Miocene times. Nature, 411, 62-66. 